\title{
Pelayanan Perusahaan Daerah Air Minum dalam Penyediaan Air Bersih di Kecamatan Pasan Kabupaten Minahasa Tenggara
}

\author{
$1^{\text {st }}$ Frisca Kuhu \\ FIS UNIMA \\ Prodi ilmu administrasi negara \\ Tondano, Indonesia \\ friscakuhu16@gmail.com \\ $2^{\text {nd }} A$ bdul R. Dilapanga \\ FIS UNIMA \\ Prodi ilmu administrasi negara \\ Tondano, Indonesia \\ abdulrahmandilapanga@unima.ac.id \\ $3^{\text {rd }}$ Jeane Mantiri \\ FIS UNIMA \\ Prodi ilmu administrasi negara \\ Tondano, Indonesia \\ Jeanelitha@unima.ac.id
}

Abstrak - Permasalahan dalam penelitian ini yaitu mengenai pelayanan Perusahaan Daerah Air Minum dalalm penyediaan air bersih di Kecamatan Pasan Kabupaten Minahasa Tenggara, dimana masih banyak masyarakat sebagai pelanggan yang seringkali tidak mendapatkan pasokan air yang cukup untuk kebutuhan mereka serta proses penyelenggaraan pelayanan tidak sesuai dengan standar pelayanan keluhan pelanggan yang telah ditetapkan. Adapun tujuan dalam penelitian ialah mendeskripsikan tentang Pelayanan Perusahaan Daerah Air Minum dalam Penyediaan Air Bersih di Kecamatan Pasan Kabupaten Minahasa Tenggara. Metode yang digunakan dalam penelitian ini ialah metode kualitatif. Teknik pengumpulan data yaitu melalui tinjauan pustaka, observasi, wawancara, dan dokumentasi. Sumber data yang diambil antaranya pimpinan perusahaaan, pegawai dan pelanggan, dengan Teknik analisis data yaitu reduksi data, penyajian data dan verifikasi data. Hasil penelitian bahwa Pelayanan Perusahaan Daerah Air Minum dalam Penyediaan Air Bersih di Kecamatan Pasan Kabupaten Minahasa Tenggara belum terselenggara dengan baik atau belum optimal, dikarenakan masih banyak masyarakat sebagai pelanggan yang belum mendapatkan air bersih sesuai dengan kebutuhan pelanggan.

Penyelenggaraan pelayanan yang dilakukan oleh pihak PDAM belum sesuai dengan standar operasional prosedur pelayanan publik yang telah ditetapkan. Sarannya untuk PDAM lebih meningkatakan pelayanan yang baik terhadap masyarakat sebagai pelanggan, serta dapat menangani keluhan-keluhan pelanggan agar kebutuhan pelanggan dapat terpenuhi, dan lebih menigkatkan pengawasan di lapangan dan tingkatkan sosialisasi kepada masyarakat.

\section{Kata Kunci : Pelayanan Publik, Air Bersih, Kepuasan Pelanggan}

\section{INTRODUCTION (HEADING 1)}

"Pembukaan Undang-Undang Dasar Republik Indonesia tahun 1945 alinea ke empat terdapat tujuan Negara Republik Indonesia salah satunya yaitu memajukan kesejahteraan umum". Untuk mewujudkan tujuan tersebut pentingnya meningkatkan pelayanan yang baik. "Pelayanan umum yang baik merupakan suatu kegiatan dalam inteaksi langsung antara seorang dengan orang lain dalam bentuk jasa maupun dalam pelayanan administrasi yang berkaitan dengan kepentingan 
umum, untuk memberikan layanan pada masyarakat hasil yang dibutuhkan masyarakat adalah kepuasan masyarakat atau kepuasan pelanggan".

Dalam (Keputusan Menteri Pendayagunaan Nomor 63 tahun 2003, menyatakan bahwa : "segala kegiatan pelayanan publik yang dilaksanakan oleh penyelenggara pelayanan publik sebagai upaya pemenuhan kebutuhan yang diperlukan". Masalah jasa pelayanan merupakan masalah yang sangat penting dalam kehidupan masyarakat yang harus diperhatikan oleh perusahaan/instansi pemerintahan. Karena hal tersebut menjadi tolak ukur terhadap keberhasilan dalam pemberian pelayanan. Pemberian pelayanan yang baik terhadapa masyarakat oleh perusahaan apalagi salah satu kebutuhan yang paling utama yang harus dipenuhi pemerintah setempat adalah penyediaan air. air merupakan hal yang tidak bisa diabaikan oleh setiap manusia, karena air meupakan sumber kehidupan.

Menurut Agung Kurniawan (2005:6) mengatakan bahwa "Pelayanan publik adalah pemberian pelayanan (melayani) keperluan orang lain atau masyarakat yang mempunyai kepentingan pada organisasi itu sesuai dengan aturan pokok dan tata cara yang telah ditetapkan". yang dikutip dalam (Pasolong, 2010:128). Dari penjelasan tersebut disimpulkan bahwa pelayaan publik adalah memberikan pelayanan kepada masyarakat yang berkepentingan di organisasi tersebut sesuai dengan aturan pokok yang telah ditetapkan. Menurut (Hardiansyah, 2011) "pelayanan dapat diartikan sebagai aktivitas yang diberikan untuk membantu, menyiapkan dan mengurus baik berupa barang atau jasa dari satu pihak kepada pihak lain.”. Sedangkan Moinir (2003: 16), mengatakan bahwa "pelayanan adalah proses pemenuhan kebutuhan melalui aktivitas orang lain secara langsung".

Pemerintah Indonesia mendirikan PDAM yang bertujuan untuk menyediakan air bersih yang struktur organisasinya berinduk pada pemerintah daerah. PDAM merupakan badan usaha yang harus melaksanakan dua fungsi yaitu memberikan pelayanan umum dan meningkatkan perekonomian daerah, dalam fungsi yang pertama yaitu memberikan pelayanan yang baik kepada masyarakat dalam hal ini penyediaan air bersih. PDAM Kabupaten Minahasa Tenggara didirikan untuk mengembangankan SPAM dan merupakan salah satu perusahaan yang bergerak dibidang jasa publik penyediaan air bersih yang berstatus Badan Usaha Milik Daerah (BUMD) dalam upaya memberikan pelayanan terhadap masyarakat dituntut untuk memberikan pelayanan yang baik kepada masyarakat atau kepada pelanggan, karena dengan demikian masyarakat akan semakin percaya dengan badan usaha ini sebagai mitra usahanya

Namun seiring waktu berjalan pelayanan PDAM Kabupaten Minahasa Tenggara sebagai penyedia air bersih tidak berjalan secara maksimal di karenakan munculnya berbagai keluhan-keluhan dari masyarakat/pelanggan yang merasa tidak puas dengan pelayanan yang dilakukan oleh PDAM, diantarannya keluhan mengenai air yang sudah beberapa hari bahkan minggu dan berbulan-bulan tidak turun kepelanggan, hal lain juga mengenai meter air yang sudah tidak berfungsi yang membuat distribusi air kepelanggan tidak berjalan lancar. Hal ini membuat para masyarakat yang hanya bergantungan pada air PDAM kesulitan untuk mendapatkan air bersih sehingga membuat mereka mencari alternatif lain mendapatkan air bersih untuk memenuhi kebutuhan mereka. Padahal didalam (Peraturan Daerah Kabuapten Minahasa Tenggara Nomor 2 tahun 2012) tentang PDAM di pasal yang ke enam menyatakan "Tugas dan tanggung jawab PDAM yaitu memberi pelayanan penyedia air minum dengan kualitas, kuantitas dan kontinuitas sesuai dengan standar yang ditetapkan".

Ada juga Hal lain yang didapati yaitu penyelenggaraan pelayanan oleh pihak PDAM dianggap kurang maksimal hal ini dikatakan oleh seorang pelanggan B.K “ waktu penyelesaian keluhan pelanggan sangat lama, waktu itu saya pergi ke kantor PDAM untuk menyampaikan 
keluhan mengenai air yang tidak turun kerumah saya dan setelah selesai menyampaikan keluhan, petugas PDAM mengatakan jika mereka akan menyelesaikan masalah ini hanya dalam 1 sampai 2 hari, tapi setelah itu tidak ada petugas yang turun kelokasi untuk mengecek malahan saya menuggu berminggu-minggu baru petugas menyelesaikan keluhan saya tersebut." Hal tersebut tidak sesuai dengan standar operasional prosedur (SOP) yang sudah ditetapkan oleh PDAM Kabupaten Minahasa Tenggara yang didalamnya dijelaskan bahwa waktu penyelesaian keluhan pelanggan diselesaikan 1-2 hari.

Penjelasan diatas mengacu pada keputusan MENPAN Nomor 63 tahun 2003 didalamnya dijelaskan mengenai Standar penyelenggaraan pelayanan publik yang terdiri dari enam indikator yaitu : "Prosedur pelayanan; waktu penyelesaian; biaya pelayanan; produk pelayanan; sarana dan prasarana; kompetensi petugas pemberi pelayanan." Dari penjelasan diatas masalah yang terjadi terkait dengan indikator kedua dan kelima yaitu waktu penyelesaian dan sarana dan prasarana, waktu penyelesaian yang tidak pasti dan sarana prasarana yang disediakan banyak yang rusak. Dalam standar oprasional prosedur mengenai pelayanan keluhan pelanggan yang sudah ditetapkan di Perusahaan Daerah Air Minum Minahasa Tenggara penyelesaian pengaduan di lakukan secepatnya 1-2 jam tergantung jenis pelayanannya dan penyelesaian masalah dapat diselesaikan dalam jangka waktu 2 hari dan kenyataan dilapangan tidak sesuai dengan aturan yang telah ditetapkan.

Berdasarkan pada penjelasan diatas penulis perlu mengkaji tentang "Pelayanan Perusahaan Daerah Air Minum Dalam Penyediaan Air Bersih Di Kecamatan Pasan Kabupaten Minahasa Tenggara”.

\section{RESEARCH METHOD}

Metode penelitian yang digunakan ialah metode penelitian kualitatif deskriptif. Seperti yang dijelaskan (sugiyono, 2014) bahwa metode penelitian kualitatif disebut sebagai metode penelitian naturalistic karena penelitiannya dilakukan pada kondisi yang alamiah. Lokasi penelitian ini terletak di PDAM Kabupaten Minahasa Tenggara. Penelitian dilakukan melalui Tinjauan pustaka, Observasi, Wawancara, Dan Dokumentasi.

\section{RESULT AND DISCUSISION}

Pelayanan Perusahaan Daerah Air Minum Dalam Penyediaan Air Bersih Di Kecamatan Pasan Kabupaten Minahasa Tenggara

Berdasarkan penelitian yang penulis lakukan dapat dikatakan bahwa pemerinth telah melaksanakan pelayanannya disini mengenai pelayanan oleh badan usaha di daerah kabupaten minahasa tenggara dalam hal ini mengenai pelayanan air bersih untuk memenuhi kebutuhan masyarakatnya dan penyelenggaraannya berdasarkan peraturan yang telah ditetapkan di organisasai tersebut).

Penyelenggaraan pelayanan yang dilakukan oleh PDAM Kabupaten Minahasa Tenggara belum sesuai dengan keputusan MENPAN Nomor 63 tahun 2003 yaitu:

\section{Prosedur pelayanan}

Hasil penelitian mengenai kesederhanaan prosedur pelayanan belum berjalan dengan baik, hal ini dilihat dalam hal pelayaannya. PDAM Kabupaten Minahasa Tenggara melaksanakan pelayanan sesuai dengan proses atau tahapan-tahapan yang dilalui dalam rangka memberikan pelayanan kepada masyarakat yaitu pelayanan penyediaan air minum.

\section{Waktu penyelesaian}

Kepastian waktu dalam pengurusan yang sudah disepakati dan menjadi suatu ukuran pasti, kapan harus selesai. Sehingga pihak pelanggan dapat merencanakan tindakan selanjutnya. Dalam pelaksanaannya pelayanan publik dapat diselesaikan dalam kurun waktu yang telah ditentukan. Sebagaimana yang 
penulis temui dilapangan bahwa tidak semua yang diatur dalam SOP pelayanan dapat dijalankan dengan optimal. Tidak terlaksananya tata kerja dan waktu-waktu penyelesaian yang ditetapkan dalam SOP juga dipengaruhi oleh sarana dan prasarana yang dimiliki, penyelesaian pelayanan di yang ditetapkan dalam kurun waktu 1 sampai 2 hari akan tetapi kenyataan yang ada sangat lama hingga berminggu-minggu.

\section{Biaya pelayanan}

Biaya pelayanan penyediaan air bersih yang dikenakan oleh PDAM Minahasa Tenggara Saat ini adalah biaya yang ditetapkan oleh pemerintah daerah sebagaimana dimuat dalam keputusan Bupati Kabupaten Minahasa Tenggara nomor 496 tahun 2015. Tarif tersebut sudah disesuaikan dengan daya beli masyarakat.

\section{Produk pelayanan}

Hasil yang telah penelitian dapat disimpulkan bahwa PDAM Kabupaten Minahasa Tenggara telah mempunyai unit-unit usaha yang sudah berjalan seperti air kemasan digelon. Dan dapat dikatakan Produk pelayanannya sudah cukup baik.

\section{Sarana dan prasarana}

Hasil penelitian dapat disimpulkan bahwa PDAM Kabupaten Minahasa Tenggara masih kurang akan sarana dan prasana yang dimiliki untuk menunjang keberhasilan pelayanan PDAM, banyak peralatan yang sudah lama atau tua dan rusak yang sangat berpengaruh pada kualitas pelayanan yang diberikan.

\section{Kompetensi petugas pemberi pelayanan}

Berdasarkan hasil penelitian yang penulis lakukan sebagaimana yang telah dijelaskan pada bagian penyajian data dapat disimpulkan bahwa kompetensi petugas yang ada di PDAM belum cukup baik karena dapat dilihat dari latar belakang pendidikan, hal lain juga kompetensi petugas PDAM tidak sesuai dengan bidangnya yang diemban saat ini yang mengakibatkan pelaksanaan pelayanan tidak berjalan secara optimal. Petugas PDAM harus lebih menigkatkan kapasitas diri mereka dengan mengikuti berbagai pelatihan-pelatihan terhadap petugas agar mereka dapat melaksanakan tugasnya dengan maksimal.

\section{CONCLUSION}

Sesuai hasil penelitian dan pembahasan diatas, dapat ditarik kesimpulan PDAM dalam Penyediaan Air Bersih di Kecamatan Pasan Kabupaten Minahasa Tenggara antara lain :

Sesuai dengan standar pelayanan publik terdapat enam indikator yang menjadi tolak ukur dalam pemberian pelayanan, hasil penelitian dari keenam indikator tersebut ada beberapa indikator yang tidak terlaksana dengan baik dan dapat dikatakan bahwa pelayanan yang diberikan oleh Perusahaan Daerah Air Minum Kabupaten Minahasa Tenggara belum maksimal karena pelaksanaannya belum sesuai dengan standar operasional prosedur yang telah ditetapkan oleh PDAM itu sendiri. sehingga tugas PDAM dalam menyediakan air kepada masyarakat dinilai kurang baik karena banyak masyarakat kurang mendapatkan pasokan air bersih.

\section{ACKNOWLEDGMENT}

Terima kasih disampaikan kepada Pimpinan Lembaga Penelitian dan Pengabdian Kepada Masyarakat (LPPM) Universitas Negeri Manado yang telah menyetujui perencanaan penyelesaian penelitian sehingga artikel ini dapat diselesaikan.

\section{REFERENSI}

[1] Agung, Kurniawan, Transformasi Pelayanan Publik, Yogyakarta:Pembaharuan, 2015

[2] Hardiansyah, Kualitas Pelayanan Publik Menuju Good Local Governance, Kualitas Pelayanan Publik, 2011 
[3] A. S. Moeinir, Manajemen Pelayanan umum di Indonesia, Bumi Aksara, 2010

[4] Pasolong, Harbani, Teori Administrasi Publik, Alfabeta, Bandung, 2010

[5] Sugiono, Metode penelitian, metode penelitian, 2014

[6] Keputusan Menteri Pendayagunaan Aparatur Negara Nomor 63 Tahun 2003 tentang Pedoman Umum Penyelenggaraan Pelayanan Publik

[7] Peraturan Daerah Kabupaten Minahasa Tenggara Nomor 2 Tahun 2012 tentang PDAM.

[8] Undang-Undang Nomor 25 Tahun 2009 tentang Pelayanan Publik. 
